\title{
Assisting in vitro fertilization by manipulating cumulus-oocyte-complexes either mechanically or enzymatically does not prevent IVF failure \\ Kümülus-oosit-komplekslerinin mekanik veya enzimatik olarak manipulasyonuyla invitro fertilizasyona yardımcı olmak IVF başarısızlığını önlemez
}

\author{
Thomas Ebner, Marianne Moser, Omar Shebl, Richard Mayer, Gernot Tews \\ Landes-Frauen-Und Kinderklinik, Kinderwunsch Zentrum, Linz, Austria
}

\section{Abstract}

Objective: This prospective study was set up in order to analyze whether additional treatment (cutting off supernumerous cumulus cells; adding hyaluronidase) of the cumulus-oocyte-complex (COC) would help to improve treatment outcome.

Material and Methods: COCs from 50 patients were prospectively subdivided into a control group A (no manipulation of $\mathrm{COC}$ ) and two study groups. In group B, surplus cumulus cells were cut off using syringes, and in the second study group COCs were incubated with a 1:11 dilution of hyaluronidase (final concentration $7 \mathrm{IU} / \mathrm{l}$ ). Main outcome measures were fertilization rate, embryo development, as well as rates of implantation, pregnancy, and live birth.

Results: Fertilization was higher in group $\mathrm{C}$ as compared to the untreated control group A $(\mathrm{p}<0.05)$. However, complete fertilization failure could not be avoided by any of the modified IVF approaches. Compaction on day 4 and blastocyst quality on day 5 were significantly improved in group $\mathrm{C}$ as compared to group $\mathrm{B}$ (but not to group $\mathrm{A}$ ). Rates of implantation, pregnancy, and live birth were not affected by any of the methods.

Conclusion: ICSI seems to be the only choice for avoiding the vast majority of fertilization failures after IVF.

(J Turkish-German Gynecol Assoc 2011; 12: 135-9)

Key words: Blastocyst, cumulus-oocyte complex, fertilization, hyaluronidase, IVF

Received: 17 March, 2011

Accepted: 10 May, 2011

\section{Özet}

Amaç: Bu prospektif çalışma, kümülus-oosit-kompleksine (KOK) ilave işlemin (çok sayıdaki kümülus hücrelerinin kesilip ayrılması; hiyaluronidaz eklenmesi) tedavi sonuçlarını iyileştirmede yardımcı olup olmayacağını analiz etmek için yapıldı.

Gereç ve Yöntemler: Elli hastadan elde edilen KOK'lar prospektif olarak bir kontrol grubuna (Grup A; KOK manipülasyonu yok) ve iki çalışma grubuna bölündü. Grup B'de, artık kümülus hücreleri şırıngalar kullanılarak kesilip ayrılmıştır ve ikinci çalışma grubunda KOK'lar hiyaluronidazın 1:11'lik dilüsyonu (son konsantrasyon $7 \mathrm{IU} / \mathrm{l}$ ) ile inkübe edildi. Başlıca sonuç ölçümleri fertilizasyon oranı, embriyo gelişmesi yanı sıra implantasyon, gebelik ve canlı doğum oranlarıydı.

Bulgular: İşlem yapılmamış kontrol grubu A'ya kıyasla fertilizasyon, grup C'de daha yüksekti $(\mathrm{p}<0.05)$. Bununla beraber, tam fertilizasyon başarısızlığı modifiye edilmiş herhangi bir IVF yaklaşımı tarafından önlenemedi. 4. günde kompaktlaşma ve 5 . günde blastokist kalitesi grup C'de grup B'ye klyasla (fakat grup A'ya değil) anlamlı olarak iyileşmişti. İmplantasyon, gebelik ve canlı doğum oranlanı bu yöntemlerin herhangi birinden etkilenmedi.

Sonuçlar: IVF sonrası fertilizasyon başarısızıklarının büyük çoğunluğundan sakınmak için tek seçenek ICSI gibi görünmektedir. (J Turkish-German Gynecol Assoc 2011; 12: 135-9)

Anahtar kelimeler: Blastokist, kümülus-oosit kompleksi, fertilizasyon, hiyaluronidaz, IVF

Geliş Tarihi: 17 Mart 2011

Kabul Tarihi: 10 Mayıs 2011

\section{Introduction}

The choice of whether to use conventional in vitro fertilization (IVF) or intracytoplasmic sperm injection (ICSI) to guarantee fertilization is mostly based on the semen quality of the male partner. ICSI was found to be highly efficient in cases of severe male infertility which would otherwise be untreatable. The success of ICSI, however, led to extensive use $(1,2)$ of this rather invasive method culminating in routine ICSI (3). Avoidance of complete fertilization failure may be the most important reason for this overuse.
The risk of fertilization failure seems to be marginal if IVF is done in normozoospermic patients $(4,5)$. However, in patients with teratozoospermia (6) or asthenozoospermia (7) these reduced sperm parameters will affect the fertilization rate. Provided that there is a sufficient number of motile spermatozoa, higher insemination concentrations may yield adequate results in terms of fertilization (8-10). However, many patients principally fulfilling the WHO (11) criteria for normozoospermia show borderline sperm parameters. Although conventional IVF may be the method of choice, embryologists tend to split the recruited oocytes into IVF and 
ICSI ones, thus rescuing approximately $10 \%$ of the cycles in which standard IVF did not work (12). This value is even higher (33\%) with mild male factor infertility (13).

The question is, whether use of a rather invasive method, such as ICSI, is really indicated, in cases in which IVF (following in vivo fertilization) would yield the same results. This prospective study was set up in order to analyze whether additional treatment (cutting off supernumerous cumulus cells; adding hyaluronidase) of the cumulus-oocyte complex (COC) would help to increase fertilization rate, embryo development, and rates of implantation and pregnancy in normozoospermic patients as well as borderline patients.

\section{Material and Methods}

According to our IRB, informed consent was obtained from all persons involved. Within a period of 6 months, a total of 50 patients (32.9 \pm 4.1 years) fulfilled our inclusion criteria, namely being under the age of 40 years, not suffering from endometriosis or PCO, and having at least 9 COCs. Patients showed either a tubal factor $(n=28)$, unexplained infertility $(n=9)$ or a combination of more than one factor $(n=12)$.

In preparation for follicular puncture, all patients treated in the Kinderwunsch Zentrum Linz, Austria, had their controlled ovarian hyperstimulation done using either a long protocol or an antagonist protocol. In the long protocol, down-regulation of the pituitary was achieved with the GnRH agonist buserelin (Suprecur ${ }^{\circledR}$, Sanofi-Aventis, Frankfurt am Main, Germany). Stimulation was initiated with human menopausal gonadotrophin (Menopur ${ }^{\circledR}$, Ferring, Kiel, Germany) or recombinant FSH (Puregon ${ }^{\circledR}$, Aesca Pharma, Vienna, Austria). In the GnRH-antagonist protocol, recombinant FSH (Puregon ${ }^{\circledR}$, Aesca Pharma, Vienna, Austria) was started on day 3 of the cycle. In addition, a GnRH-antagonist (Orgalutran ${ }^{\circledR}$; Organon, Vienna, Austria) was administered after 5-6 days of stimulation, depending on the presence of a $12-13 \mathrm{~mm}$ follicle. In all patients ovulation was induced with 10,000 IU human chorionic gonadotrophin (hCG, Pregnyl ${ }^{\circledR}$, Aesca Pharma, Vienna, Austria). Oocyte retrieval was carried out transvaginally under ultrasound guidance 36 hours after hCG administration. Cumulus-oocyte complexes (COC) were collected in BM1 medium (Eurobio, Les Ulis, France) and incubated for two to three hours until IVF.

Meanwhile, the ejaculate of patients was incubated in a sperm selecting chamber (Zech-selector, AssTIC Medizintechnik $\mathrm{GmbH}$, Leutsch, Austria,) which accumulates an adequate number of motile sperm without exposure to centrifugation stress (14). The Zech device consists of two concentric wells overlaid by a U-ring and a cover glass. In detail, progressive motile spermatozoa migrate from the ejaculate in the outer well to concentrate in the medium-filled inner well by using a capillary bridge created by the overlying U-ring. After approximately 1-2 hours a $500 \mu$ l sperm sample was taken from the central chamber, analyzed and used for insemination.

COCs were split into a control group A (no manipulation) and two study groups. In the study groups, COCs were either mechanically manipulated by cutting off their supernumerous cumulus cells with syringes (group B) or enzymatically treated (group C) by diluting the culture medium at a rate of 11:1 with $80 \mathrm{IU}$ of hyaluronidase (Origio, Copenhagen, Denmark). In detail, $50 \mu$ l of enzyme were pipetted into $500 \mu$ l of sperm solution.

Treated and untreated COCs as well as corresponding embryos were inseminated in groups in 4-well-dishes (approximately 25-50,000 sperms per egg). From the zygote stage on, concepti were cultured in small drops $(50 \mu \mathrm{l})$ of either sequential medium (EmbryoAssist ${ }^{\circledR}$ and BlastAssist ${ }^{\circledR}$, MediCult, Copenhagen, Denmark) or global medium (GM501 Cult ${ }^{\circledR}$; Gynemed, Lensahn, Germany).

Fertilization was checked 18-21 hours post insemination. Two aligned pronuclei were considered to be a regular fertilization. If both pronuclei were not aligned, of uneven size and/ or situated in the periphery, these types were separated since they were thought to have impaired development $(15,16)$. At the cleavage stage, the number and size of blastomeres were taken into account as well as the degree of fragmentation and multinucleation. On day 4, embryos were screened for signs of compaction. On day 5 , survival to blastocyst stage and blastocyst quality were evaluated taking both cell lineages into account. It is noteworthy that the quality of inner cell mass and trophectoderm could only be analyzed from the full blastocyst stage onwards (17).

With adequate consideration of all prognostic markers (day 1 to day 5$)$ a maximum of 2 embryos $(n=16)$ or blastocysts $(n=30)$ were chosen for intrauterine transfer. Therefore, all patients were placed in the lithotomy position during embryo replacement and neither sedation nor anaesthesia was used. Embryos were loaded into a Gynetics catheter (Gynemed, Lensahn, Germany) using $<10 \mu$ l of BlastAssist medium 2 or GM501 Cult and then expelled approximately $1 \mathrm{~cm}$ from the fundus.

A total of 9,000 IU hCG (Pregnyl ${ }^{\circledR}$, Organon, Vienna, Austria) were injected on the day of ovum pick-up (3,000 IU), the day of transfer (3,000 IU) and day 3 (1,500 IU) and 6 (1,500 IU) post transfer to support the luteal phase. No hCG was administered in case of OHSS. In addition, progesterone was given from the day after follicular puncture until the day of the pregnancy test. This was given either in the form of house-made vaginal suppositories (400mg) or as vaginal tablets (Utrogestan ${ }^{\circledR}$, Meda Pharma, Vienna, Austria, 300mg).

Seventeen days after intrauterine transfer, the blood concentration of hCG was measured. Clinical pregnancy was determined by visualization of at least one gestational sac with positive heart activity 4 weeks after embryo transfer. Subclinical pregnancy showed no fetal heartbeat.

The chi-square test was used to analyze nominal variables in the form of frequency tables. Ordinal variables were analyzed with the Mann-Whitney U test. Statistical significance was accepted if p-value was $<0.05$.

\section{Results}

A total of 592 COCs were collected in 50 patients. Unfortunately, no fertilization occurred in four patients (8\%) regardless of the IVF method used. In the remaining 46 patients, $70.6 \%$ $(398 / 564)$ of the oocytes showed two pronuclei on day 1 of 
culture. Thirty-five zygotes were tripronuclear (6.2\%), whereas only 2 zygotes showed one pronucleus $(0.4 \%)$. Eighteen eggs $(3.2 \%)$ were still immature (GV stage) at the time of fertilization check.

On day 2 of development, 338 embryos out of 398 zygotes (85.0\%) showed regular cleavage, i.e. without multinucleation. The number and quality of embryos allowed blastocyst culture in only 30 patients $(60 \%)$. In this special cohort, the overall blastulation rate was 150/280 (53.6\%). The percentage of good quality blastocysts was approximately 79\% (119/150).

In those patients finally having an embryo or blastocyst transfer $(n=46), 24$ pregnancies could be achieved (52.2\%). Since 2 biochemical pregnancies occurred, clinical pregnancy and life birth rate dropped to $47.8 \%$. In terms of multiple pregnancy six twins (25\%) were observed, but in four cases a vanishing twin occurred. The corresponding implantation rate was $32.6 \%$ (30/92).

Table 1 indicates that, in group A, significantly more $(\mathrm{p}<0.05) \mathrm{GV}$ stage ovae were found at the time of fertilization check than in the two study groups $(\mathrm{p}<0.01)$. Fertilization was higher in group $\mathrm{C}$ as compared to the untreated control group $\mathrm{A}(\mathrm{p}<0.05)$. In addition, significantly fewer $(\mathrm{p}<0.001) 3 \mathrm{PN}$ zygotes were found in the enzymatically treated group $\mathrm{C}$. Embryo quality on days 2 and 3 (data not shown) were comparable between all three groups. Blastocyst formation was significantly higher $(\mathrm{p}<0.05)$ in group $\mathrm{C}$ as compared to group $\mathrm{B}$ (but not to group $\mathrm{A}$ ). The same also holds for blastocyst quality $(\mathrm{p}<0.05)$.

Although low sample numbers and mixed transfers do not support statistical analysis, results shown in Table 2 indicate that embryos derived from enzymatically treated COCs indeed have a higher implantation potential. In detail, 16/24 (66.7\%) patients having at least one embryo transferred from group $\mathrm{C}$ achieved pregnancy, which is higher than for groups B (50\%) and $\mathrm{A}(45.5 \%)$.

\section{Discussion}

Decisions concerning the treatment option for assisted reproduction (IVF or ICSI) are usually taken after evaluation of male fertility factors, or after taking into account the results of previous IVF attempts. There are no widely accepted criteria, so decisions for couples with male subfertility are often empirical and may lead to complete fertilization failure after IVF, or to the unnecessary use of ICSI.

In principle, it is advisable to use the least invasive method of insemination, namely IVF, whenever possible. This decision is of course a difficult balancing act. One problem encountered is that no exact cut-off value for sperm parameters is available indicating to an embryologist whether to use IVF or ICSI. Naturally, sperm number and motility after processing of the ejaculate will facilitate the decision of which method to choose. However, in terms of morphology, the information from the literature is not conclusive. A report by Zollner et al. (18)

Table 2. Pregnancy outcome in control and study groups after double embryo or blastocyst transfer

\begin{tabular}{|l|c|c|c|c|}
\hline $\mathbf{n}$ transfer & $\begin{array}{c}\text { COC not } \\
\text { manipulated }\end{array}$ & $\begin{array}{c}\text { COC treated } \\
\text { mechanically }\end{array}$ & $\begin{array}{c}\text { COC treated } \\
\text { enzymatically }\end{array}$ & PR \\
\hline 6 & 2 & 0 & 0 & $2(33.3)$ \\
\hline 10 & 1 & 1 & 0 & $4(40.0)$ \\
\hline 6 & 1 & 0 & 1 & $4(66.7)$ \\
\hline 6 & 0 & 2 & 0 & $2(33.3)$ \\
\hline 8 & 0 & 1 & 1 & $6(75.0)$ \\
\hline 10 & 0 & 0 & 2 & $6(60.0)$ \\
\hline
\end{tabular}

Values in parentheses are percentages. COC: Cumulus-oocyte complex; PR: Pregnancy rate

Table 1. Comparison of fertilization rates and embryonic development in control and study groups

\begin{tabular}{|c|c|c|c|c|}
\hline & $\begin{array}{c}\text { COC not } \\
\text { manipulated }\end{array}$ & $\begin{array}{l}\text { COC treated } \\
\text { mechanically }\end{array}$ & $\begin{array}{l}\text { COC treated } \\
\text { enzymatically }\end{array}$ & p-value \\
\hline $\mathrm{n}$ & 208 & 184 & 172 & \\
\hline PI & $0^{\mathrm{a}, \mathrm{b}}$ & $10(5.4)^{\mathrm{a}}$ & $8(4.7) b$ & $<0.01$ \\
\hline $2 \mathrm{PN}$ & $144 / 208(69.2)^{c}$ & $124 / 174(71.3)$ & $130 / 164(79.3)^{\mathrm{c}}$ & $<0.05$ \\
\hline OPN & $44(21.2)$ & $34(18.5)$ & $28(16.3)$ & \\
\hline $1 \mathrm{PN}$ & 0 & $2(1.1)$ & 0 & \\
\hline 3PN & $20(9.6)^{d}$ & $14(7.6)^{\mathrm{e}}$ & 0d,e & $<0.001$ \\
\hline Cell number day 2 & $3.6 \pm 1.0$ & $3.8 \pm 1.1$ & $3.6 \pm 1.4$ & \\
\hline Fragmentation day $2(\%)$ & $20.7 \pm 17.1$ & $23.8 \pm 18.1$ & $18.9 \pm 17.5$ & \\
\hline n blastocyst culture & 102 & 86 & 92 & \\
\hline n compacting day 4 & $48(47.1)$ & $31(36.1)^{f}$ & $49(53.3)^{\mathrm{f}}$ & $<0.05$ \\
\hline n blastocyst & $54(52.9)$ & $42(48.8)$ & $54(58.7)$ & \\
\hline n good quality blastocyst & $42(77.8)$ & $29(69.0)^{\mathrm{g}}$ & $48(88.9)^{\mathrm{g}}$ & $<0.05$ \\
\hline
\end{tabular}


found $8 \%$ normal spermatozoa to be a threshold significantly discriminating between fertilization (66.7\% vs. $35.7 \%)$. Lundin et al. (19) suggested even lower thresholds (5\%) because they neither saw an impaired fertilization rate nor an increase in abortion rate. However, since none of the patients in our prospective study showed a morphology of less than $10 \%$, teratozoospermia was no reason for cases of failed fertilization. Unfortunately, facilitating access of the sperms to the egg by additional manipulation (groups B and C) could not prevent complete fertilization failure. Most likely, this happened due to immunological rejection.

Oocyte maturity and quality at the time of retrieval are difficult to assess as the egg is obscured by a large cumulus mass impairing adequate scoring. From the early years of IVF, it became evident that assessment of egg maturation in stimulated cycles is rather imprecise (20-23). The reported failure of adequate prognosis has more recently been confirmed by Ebner et al. (24) who noted a discrepancy between the actual appearance of the COC and the nuclear maturity of the corresponding egg. Interestingly, some $26 \%$ of presumably immature oocytes turned out to be at metaphase II, whereas approximately $11 \%$ of expected metaphase-II eggs did not show a first polar body. Since the present analysis carefully tried to equally distribute COCs according to morphology, i.e. the presence of blood clots (24) and presumed maturity, the observed difference in prophase I oocytes on the day of fertilization check must have a biological reason. It is very likely that ovae from untreated COCs (group A) have a higher potential to mature in vitro since more cumulus cells stay attached to the zona pellucida, which is not the case if surplus cumulus cells are cut off or digested (25).

This is the first report to show that prolonged incubation (overnight) with commercially available hyaluronidase has no negative effect on further outcome. Most commercially available hyaluronidases have a concentration of $80 \mathrm{IU} / \mathrm{l}$ which is only a tenth of the critical threshold above which parthenogenetic activation may occur (26). For reducing the theoretical risk of harming the oocyte, an approximately. 10-fold dilution was applied in group C (approximately $7 \mathrm{IU} / \mathrm{l}$ ). On the other hand, by doing so, no benefit was observed in terms of further preimplantation development as compared to untreated COCs. The highest fertilization rate in group $\mathrm{C}$ primarily suggests that enzymatic digestion facilitates access of motile spermatozoa to the zona pellucida.

Nevertheless, cleavage results were significantly better than in the mechanically treated group B. This indicates that cutting off surplus cumulus cells will harm the corresponding gametes by either altering the shape of the gamete (27) or generating shearing forces via transzonal processes.

To summarize, it can be stated that, although none of the modified IVF approaches showed a clear relation to rates of implantation, pregnancy, and live birth, mechanical manipulation of the COC is associated with certain drawbacks and should be avoided. This is all the more true as it was shown that oocyte morphology cannot be rescued by cutting off suspicious tissue or blood clots from the COC (24). A tendency towards a higher pregnancy rate in group $\mathrm{C}$ would require a more detailed study in a larger number of patients.
Most importantly, it has to be emphasized that none of the assisted IVF technologies will rescue a cycle of failed IVF. Thus, in cases of borderline sperm quality, ICSI seems to be the only choice in order to avoid complete fertilization failure.

\section{Conflict of interest}

No conflict of interest was declared by the authors.

\section{References}

1. Moreno C, Ruiz A, Simon C, Pellicer A, Remohi J. Intracytoplasmic sperm injection as a routine indication in low responder patients. Hum Reprod 1998; 13: 2126-9. [CrossRef]

2. Saito H, Saito T, Kaneko T, Sasagawa I, Kuramoto T, Hiroi M. Relatively poor oocyte quality is an indication for intracytoplasmic sperm injection. Fertil Steril 2000; 73, 465-9. [CrossRef]

3. Fishel S, Aslam I, Lisi F, Rinaldi L, Timson J, Jacobson M, et al. Should ICSI be the treatment of choice in all cases of in-vitro conception. Hum Reprod 2000; 15: 1278-83. [CrossRef]

4. Staessen C, Camus M, Clasen K, De Vos A, Van Steirteghem A. Conventional in-vitro fertilization versus intracytoplasmic sperm injection in sibling oocytes from couples with tubal infertility and normozoospermic semen. Hum Repro 1999; 14: 2474-9. [CrossRef]

5. Bukulmez O, Yarali H Yucel A, Sari T, Gurgan T. Intracytoplasmic sperm injection versus in vitro fertilization for patients with a tubal factor as their sole cause of infertility: a prospective, randomized trial. Fertil Steril 2000; 73: 38-42. [CrossRef]

6. Pisarska MD, Casson PR, Cisneros PL, Lamb DJ, Lipshultz LI, Bust $\mathrm{JE}$, et al. Fertilization after standard in vitro fertilization versus intracytoplasmic sperm injection in subfertile males using sibling oocytes. Fertil Steril 1999; 71: 627-32. [CrossRef]

7. Verheyen G, Tournaye H, Staessen C, De Vos A, Vandervorst M, Van Steirteghem A. Controlled comparison of conventional in-vitro fertilization and intracytoplasmic sperm injection in patients with asthenozoospermia. Hum Reprod 1999; 14: 2313-9. [CrossRef]

8. Cowan DB, Santis M, Keefe T, Hargreaves CA, Howell RJ, Homa ST. A bridge to intracytoplasmic sperm injection - high insemination concentrations benefit patients who have a reduced chance of fertilization with standard in-vitro fertilization. Hum Reprod 1996; 11: 1985-9.

9. Oehninger S, Kruger TF, Simon D, Jones D, Mayer J, Lanzendorf S, et al. A comparative analysis of embryo implantation potential in patients with severe teratozoospermia undergoing in-vitro fertilization with a high insemination concentration or intracytoplasmic sperm injection. Hum Reprod 1996; 11: 1086-9.

10. Check ML, Check JH, Lee G, Summers-Chase D, Choe JK. Increasing sperm concentration to adjust for subnormal sperm morphology did not adversely affect implantation after embryo transfer. Arch Androl 2001; 46: 177-82.

11. World Health Organization (1999) Laboratory manual for the examination of human semen and sperm-cervical mucus interaction, 4th edn. Cambridge University Press, Cambridge.

12. Hershlag A, Paine T, Kvapil G, Feng H, Napolitano B. In-vitro fertilization - intracytoplasmic sperm injection split: an insemination method to prevent fertilization failure. Fertil Steril 2002; 77: 229-32. [CrossRef]

13. Plachot M, Belaisch-Allart J, Mayenga JM, Chouraqui A, Tesquier L, Serkine AM. Outcome of conventional IVF and ICSI on sibling oocytes in mild male factor infertility. Hum Reprod 2002; 17: 362-9. [CrossRef]

14. Ebner T, Shebl O, Moser M, Mayer RB, Arzt W, Tews G. An easy sperm processing technique allowing for exclusive accumulation and later usage of DNA strand break-free spermatozoa. Reprod Biomed Online 2011; 22: 37-43. [CrossRef] 
15. Scott LA, Smith S. The successful use of pronuclear embryo transfers the day following oocyte retrieval. Hum Reprod 1998; 13: 1003-13. [CrossRef]

16. Scott L, Alvero R, Leondires M und Miller B. The morphology of human pronuclear embryo is positively related to blastocyst development und implantation. Hum Reprod 2000; 15: 2394-403. [CrossRef]

17. Gardner DK, Lane M, Stevens J, Schlenker T, Schoolcraft WB. Blastocyst score affects implantation and pregnancy outcome: towards a single blastocyst transfer. Fertil Steril 2000; 73: 1155-8. [CrossRef]

18. Zollner U, Schleyer M, Steck T. Evaluation of a cut-off value for normal sperm morphology using strict criteria to predict fertilization after conventional in-vitro fertilization and embryo transfer in asthenozoospermia. Hum Reprod 1996; 11: 2155-61.

19. Lundin K, Söderlund B, Hamberger L. The relationship between sperm morphology and rates of fertilization, pregnancy and spontaneous abortion in an in-vitro fertilization/intracytoplasmic sperm injection programme. Hum Reprod 1997; 12: 2676-81. [CrossRef]

20. Laufer N, Tarlatzis BC, DeCherney AH. Asynchrony between human cumulus-corona cell complex and oocyte maturation after human menopausal gonadotropin treatment for in vitro fertilization. Fertil Steril 1984; 42: 366-72. [CrossRef]

21. Hammitt DG, Syrop CH, Van Voorhis BJ, Walker DL, Miller TM, Barud KM, Hood CC. Prediction of nuclear maturity from cumu- lus-coronal morphology: influence of embryologist experience. J Assist Reprod Genetics 1992; 9: 439-46. [CrossRef]

22. Hammitt DG, Syrop CH, Van Voorhis BJ, Walker DL, Miller TM, Barud KM. Maturational asynchrony between oocyte cumulus-coronal morphology and nuclear maturity in gonadotropin-releasing hormone agonist stimulations. Fertil Steril 1993; 59: 375-81.

23. Rattanachaiyanont M, Leader A and Léveillé MC. Lack of correlation between oocyte-corona-cumulus complex morphology and nuclear maturity of oocytes collected in stimulated cycles for intracytoplasmic sperm injection. Fertil Steril 1999; 71: 937-40. [CrossRef]

24. Ebner T, Moser M, Shebl O, Sommergruber M, Yaman C, Tews G. Blood clots in the cumulus-oocyte complex predict poor oocyte quality and post-fertilization development. Reprod Biomed Online 2008; 16: 801-7. [CrossRef]

25. Ebner T, Moser M, Sommergruber M, Shebl O, Tews G. Incomplete denudation of oocytes prior to ICSI enhances embryo quality and blastocyst development. Hum Reprod 2006; 21: 2972-7. [CrossRef]

26. Van de Velde H, Nagy ZP, Joris H, De Vos A, Van Steirteghem AC. Effects of different hyaluronidase concentrations and mechanical procedures for cumulus cell removal on the outcome of intracytoplasmic sperm injection. Hum Reprod 1997; 12: 2246-50. [CrossRef]

27. Ebner T, Shebl O, Moser M, Sommergruber M, Tews G. Developmental fate of ovoid oocytes. Hum Reprod 2008; 23: 62-6. [CrossRef] 